Open Access

\title{
Identification of a botanical inhibitor of intestinal diacylglyceride acyltransferase 1 activity via in vitro screening and a parallel, randomized, blinded, placebo-controlled clinical trial
}

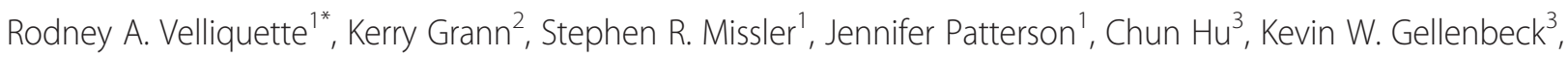
Jeffrey D. Scholten ${ }^{1}$ and R. Keith Randolph ${ }^{3}$

\begin{abstract}
Background: Diacylglyceride acyltransferase 1 (DGAT1) is the enzyme that adds the final fatty acid on to a diacylglyceride during triglyceride (TG) synthesis. DGAT1 plays a key role in the repackaging of dietary TG into circulating TG rich chylomicrons. A growing amount of research has indicated that an exaggerated postprandial circulating TG level is a risk indicator for cardiovascular and metabolic disorders. The aim of this research was to identify a botanical extract that inhibits intestinal DGAT1 activity and attenuates postprandial hypertriglyceridemia in overweight and obese humans.
\end{abstract}

Methods: Twenty individual phytochemicals and an internal proprietary botanical extract library were screened with a primary cell-free DGAT1 enzyme assay that contained dioleoyl glycerol and palmitoleoyl Coenzyme A as substrates plus human intestinal microsomes as the DGAT1 enzyme source. Botanical extracts with IC50 values $<100 \mathrm{\mu g} / \mathrm{mL}$ were evaluated in a cellular DGAT1 assay. The cellular DGAT1 assay comprised the analysis of ${ }^{14} \mathrm{C}$ labeled TG synthesis in cells incubated with ${ }^{14} \mathrm{C}$-glycerol and $0.3 \mathrm{mM}$ oleic acid. Lead botanical extracts were then evaluated in a parallel, double-blind, placebo-controlled clinical trial. Ninety healthy, overweight and obese participants were randomized to receive $2 \mathrm{~g}$ daily of placebo or individual botanical extracts (the investigational product) for seven days. Serum TG levels were measured before and after consuming a high fat meal (HFM) challenge (0.354 L drink/ shake; $77 \mathrm{~g}$ fat, $25 \mathrm{~g}$ carbohydrate and $9 \mathrm{~g}$ protein) as a marker of intestinal DGAT1 enzyme activity.

Results: Phenolic acids (i.e., gallic acid) and polyphenols (i.e., cyanidin) abundantly found in nature appeared to inhibit DGAT1 enzyme activity in vitro. Four polyphenolic rich botanical extracts were identified from in vitro evaluation in both cell-free and cellular model systems: apple peel extract (APE), grape extract (GE), red raspberry leaf extract (RLE) and apricot/nectarine extract (ANE) (IC50 = 1.4, 5.6, and 10.4 and $3.4 \mu \mathrm{g} / \mathrm{mL}$, respectively). In the seven day clinical trial, compared to placebo, only GE significantly reduced the baseline subtracted change in serum TG AUC following consumption of the HFM (AUC $=281 \pm 37$ vs. $181 \pm 30 \mathrm{mg} / \mathrm{dL}^{*} \mathrm{~h}$, respectively; $P=0.021$ ). Chromatographic characterization of the GE revealed a large number of closely eluting components containing proanthocyanidins, catechins, anthocyanins and their secondary metabolites that corresponded with the observed DGAT1 enzyme inhibition in the cell-free model.

Conclusion: These data suggest that a dietary GE has the potential to attenuate postprandial hypertriglyceridemia in part by the inhibition of intestinal DGAT1 enzyme activity without intolerable side effects.

Trial registration: This trial was registered with ClinicalTrials.gov NCT02333461

\footnotetext{
* Correspondence: rod.velliquette@amway.com

'Department of Analytical Sciences, Amway R\&D, 7575 Fulton St., Building

50-2D, Ada, MI 49355, USA

Full list of author information is available at the end of the article
}

C Biomed Central
(C) 2015 Velliquette et al. Open Access This article is distributed under the terms of the Creative Commons Attribution License (http://creativecommons.org/licenses/by/4.0), which permits unrestricted use, distribution, and reproduction in any medium, provided the original work is properly credited. The Creative Commons Public Domain Dedication waiver (http://creativecommons.org/publicdomain/zero/1.0/) applies to the data made available in this article, unless otherwise stated. 


\section{Background}

Overweight and obese conditions develop as a result of chronic energy imbalance, arising when energy input exceeds energy expenditure. Sedentary lifestyle and the availability of inexpensive, highly palatable, energy-dense foods that are high in fat and refined carbohydrates are major drivers of the global obesity epidemic [1]. These foods displace healthier options, such as fruits and vegetables, from the diet and promote storage of excess calories as body fat. Fruits and vegetables have long been known to be important sources of vitamins, minerals and fiber and are increasingly recognized for the complex and diverse collection of health-promoting phytochemicals they contribute to the diet [2].

Elevated blood triglyceride (TG), another consequence of an eating pattern that is high in fat and refined carbohydrate, is recognized as an independent risk factor for conditions such as metabolic syndrome, type II diabetes and cardiovascular disease [3]. In addition, there is growing evidence that postprandial TG levels strengthens the assessment of metabolic and cardiovascular risk [4-7]. Zilversmit [8] first reported that postprandial hyperlipidemia could be a significant metabolic factor contributing to the development of atherogenesis. He proposed that postprandial TG rich chylomicrons are as atherogenic as circulating low-density lipoprotein cholesterol (LDL-C), and emphasized the need for studies that address this phenomenon. Research around postprandial hypertriglyceridemia continues to be a topic of great interest [4-7, 9-12]. In fact, postprandial TG levels have been reported to be more predictive of cardiovascular risk compared to fasting TG $[9,13]$. The circulating TG levels in response to a meal are dependent on many variables including total amount and type of dietary fats, fasting TG levels, gastric emptying, intestinal break down, absorption and secretion of TG and systemic catabolism. Given humans spend a significant amount of time in the postprandial state, the chronic systemic exposure of postprandial hypertriglyceridemia could contribute to multiple metabolic disorders via multiple mechanisms [14-21]. Therefore, nutritional approaches that target postprandial hypertriglyceridemia in response to a fatty meal is mechanism that could have meaningful impact on cardiovascular and metabolic risks and health.

Diacylglycerol acyltransferase 1 (DGAT1) in enterocytes is a key enzyme involved in the assembly of TG from dietary fatty acids [22]. In the postprandial state, intestinal DGAT1 generated TG are secreted into the lymphatic system, mainly as chylomicron particles, and then enter the blood circulation via the thoracic duct (Fig. 1). DGAT1-deficient (Dgat1-/-) mice are resistant to high fat diet-induced obesity due in part to an increase in systemic energy expenditure induced by body heat loss [23]. It was later reported that intestinal only
DGAT1 deficiency could reproduce many of the high fat diet induced phenotypes of the Dgat1-/- mouse [24]. In addition, intestinal only expression of DGAT1 abolished the anti-obesity phenotypes of Dgat1-/- mouse while on a high fat diet [25]. These animal studies lead to the pharmaceutical development of intestinal DGAT1 inhibitors as a mechanistic approach to mitigate metabolic risks associated with elevated postprandial TG levels [12, 26, 27]. These and other reports suggest that delaying and decreasing postprandial circulating TG levels with intestinal DGAT1 inhibition could facilitate the improvement of metabolic and cardiovascular risks and maintenance of health [22, 24, 28-31]. However, a hurdle facing pharmaceutical inhibitors thus far has been the compounds are so selective and potent that the gastrointestinal side effect profiles, like nausea, diarrhea and vomiting are not tolerated [12]. Therefore, nutritional strategies targeting postprandial TG levels via DGAT1 inhibition without intolerable side effects could have meaningful impact on cardiovascular and metabolic risks and health.

We are not aware of any published prospective human studies that provide evidence for a botanical inhibitor of intestinal DGAT1 activity indicated by measuring serum TG during a high fat meal (HFM). The aim of this research was to identify a botanical extract that inhibits intestinal DGAT1 activity and attenuates postprandial hypertriglyceridemia in overweight and obese humans. This report presents in vitro and in vivo evidence supporting inhibition of intestinal DGAT1 activity via a botanical extract that may have the potential to improve metabolic imbalance related to postprandial hypertriglyceridemia.

\section{Methods}

\section{Clinical trial methodology}

The randomized, double-blind, placebo-controlled clinical trial was approved by the New England Institutional Review Board (Wellesley, MA, USA) and was conducted in compliance with the Declaration of Helsinki and the International Conference on Harmonization Guidelines. Informed consent to participate in the research study was obtained from all study participants using an IRBapproved consent form (NEIRB \# 12-103). The study was conducted from May through August, 2012 at Radiant Research, Chicago, IL.

A total of 158 healthy overweight and obese individuals were screened based on medical history, vital signs, physical exam, height/weight, concomitant medication use, serum chemistry, hematology and lipid panel as well as a urine pregnancy test for females of childbearing age. Participants were excluded if they had a fasting TG > $200 \mathrm{mg} / \mathrm{dL}$ or any abnormal biochemical value deemed to be clinically significant by the Principal Investigator. Women were excluded if they were pregnant or lactating or were of child bearing age and unwilling to use birth 


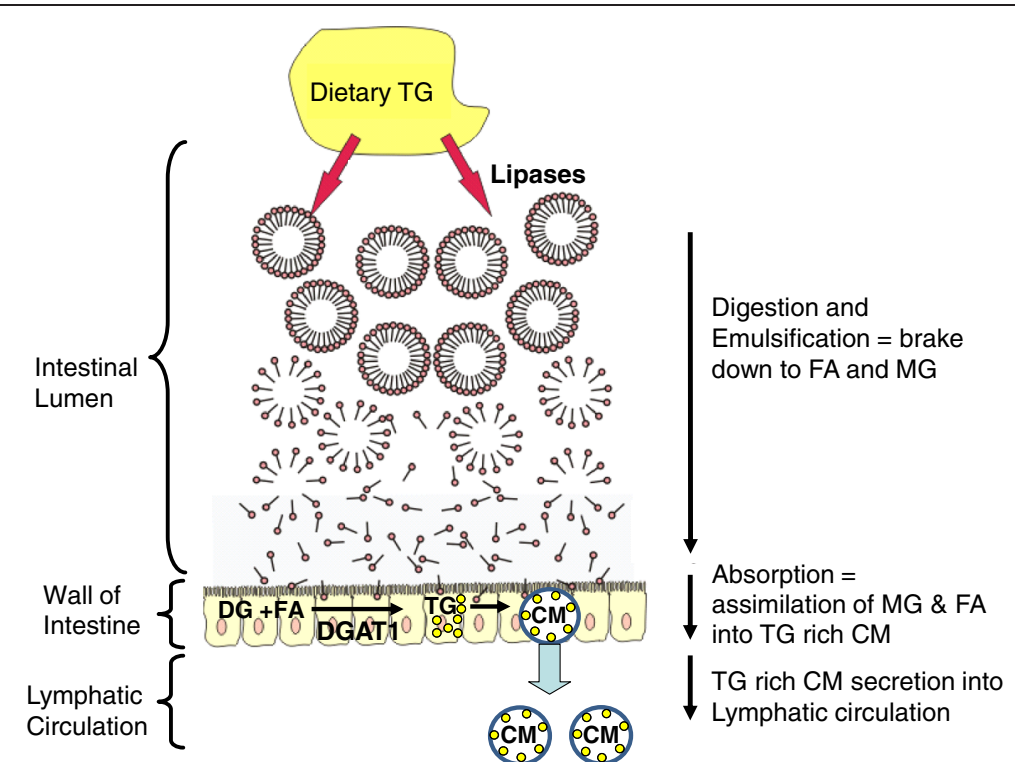

Fig. 1 Role of DGAT1 in the assimilation of dietary TG into circulating TG rich chylomicrons (CM). Dietary TG are first broken down into monoacylglycerides (MG) and fatty acids (FA) by a host of pancreatic lipases. MG and FA are then absorbed into the small intestinal enterocytes and repackaged into diacylglyercides (DG) by monoacylglyceride acyltransferase transferase. DGAT1 then acylates the DG into TG (yellow circles), which are incorporated into CM and secreted into the lymphatic circulation then enter the blood circulation via the thoracic duct

control. The exclusion criteria included an alcoholic beverage intake $>14$ drinks per week and history of gastric bypass or other surgery to physically alter the gastrointestinal tract. Concomitant use of medications for blood pressure, coagulation disorders, high cholesterol, gastroesophageal reflux, or any medication with vasoconstricting properties such as serotonin reuptake inhibitors or monoamine oxidase inhibitors was an additional exclusion criteria.

Subjects were also excluded if they had consumed antibiotics in the previous week, dietary supplements (e.g. vitamins, minerals and herbal products, including herbal drinks) within one week, fish oil supplements or consumption of fatty fish more than once per week within eight weeks of the trial. Those who were eligible to participate were instructed to maintain their normal diet and physical activity pattern throughout the duration of the study.

\section{Investigational product (Botanical Extracts)}

The investigational product doses were packed in opaque two piece hard shell capsules. Each capsule had a fill weight of $333 \mathrm{mg}$ and contained either $100 \%$ extract or placebo. The placebo was comprised of silicified microcrystalline cellulose, magnesium stearate, modified cellulose gum, silicon dioxide, dextrose, corn starch and caramel color. Each qualified participant received one bottle of investigational product that contained placebo, apple peel extract (APE), grape extract (GE), red raspberry leaf extract (RLE) or apricot/nectarine extract (ANE). See Table 1 for botanical extract details. Participants were instructed to ingest the investigational product as six capsules once daily (total of

Table 1 Botanical extract information

\begin{tabular}{|c|c|c|c|c|c|c|c|}
\hline Extract & Manufacturer & Genus/Species & Plant Part & Standardization & $\begin{array}{l}\text { Extraction } \\
\text { Solvent }\end{array}$ & $\begin{array}{l}\text { Extraction } \\
\text { Ratio }\end{array}$ & Excipient \\
\hline Apple Peel & Cyvex Irvine, CA & Malus Domestica & Skin & $\begin{array}{l}80 \% \text { Polyphenol, } \\
5 \% \text { Phlorizin }\end{array}$ & $\begin{array}{l}\text { Ethanol/ } \\
\text { Water }\end{array}$ & $115: 1$ & None \\
\hline Grape & Cyvex Irvine, CA & Vitus Vinifera & Pulp, Skin, Seed & $\begin{array}{l}75 \% \text { Total Polyphenol, } \\
50 \% \text { Oligomeric } \\
\text { Proanthocyanidin }\end{array}$ & $\begin{array}{l}\text { Ethanol/ } \\
\text { Water }\end{array}$ & $8000: 1$ & None \\
\hline $\begin{array}{l}\text { Red } \\
\text { Raspberry Leaf }\end{array}$ & $\begin{array}{l}\text { Naturex South } \\
\text { Hackensack, NJ }\end{array}$ & Rubus Idaeus & Leaf & $6 \%$ Ellagic Acid & $\begin{array}{l}\text { Ethanol/ } \\
\text { Water }\end{array}$ & $4: 1$ & $\begin{array}{l}\text { Maltodextrin, } \\
\text { Silica }\end{array}$ \\
\hline $\begin{array}{l}\text { Apricot/ } \\
\text { Nectarine }\end{array}$ & $\begin{array}{l}\text { PLT Health } \\
\text { Morristown, NJ }\end{array}$ & $\begin{array}{l}\text { Prunus Armeniaca, } \\
\text { Prunus Persica }\end{array}$ & Whole Fruit & 50 \% Polyphenol & $\begin{array}{l}\text { Ethanol/ } \\
\text { Water }\end{array}$ & $40: 1$ & None \\
\hline
\end{tabular}


$2 \mathrm{~g} / \mathrm{d}$ ) with the morning meal for seven days. Participants returned their bottle of investigational product at the final study visit.

\section{Clinical trial procedures}

Ninety participants were randomly assigned in blocks of five to one of the five test groups. The test groups within each block were allocated using a random number generator (Statistical Analysis Program, Cary, $\mathrm{NC}$ ). The randomization codes were kept at a separate location in the Quality Assurance Department of Radiant Development.

Participants were instructed to fast for $12 \mathrm{~h}$ and refrain from strenuous physical activity the morning of each study day (Day 1 and 7). A standardized high fat meal (HFM) drink/shake containing $77 \mathrm{~g}$ fat, $25 \mathrm{~g}$ carbohydrate, and $9 \mathrm{~g}$ protein (Table 2) was administered over a $15 \mathrm{~min}$ period at baseline (day 1 ) and following one week (day 7) of placebo or investigational product. The HFM composition was similar to the recommendations reported by Kolovou et al. [32]. At the final study day (day 7 ), the final dose of the placebo or investigational product was consumed $10 \mathrm{~min}$ before the time zero blood draw and consumption of the HFM. On both study days, blood was drawn via standard venipuncture immediately before and 2, 4, and $6 \mathrm{~h}$ after consuming the HFM.

Compliance was evaluated by participant interview and counting the investigational product capsules returned to the clinic at final study day. Non-compliance was defined as consumption of $<80 \%$ of the scheduled intake of investigational product. Due to the short intervention period, participants with compliance below this threshold were removed from the study efficacy analysis. Figure 2 details the clinical trial participant flow.

Safety and tolerability were assessed by measuring changes in serum chemistry, hematology, vital signs, body weight and reported adverse events.

\section{Outcome variables}

The primary outcome variable was serum TG levels over a $6 \mathrm{~h}$ time period following consumption of a standardized HFM. Serum total cholesterol (TC), high-density lipoprotein cholesterol (HDL-C) and TG were measured on the

Table 2 Recipe of the HFM

\begin{tabular}{lllll}
\hline & $\begin{array}{l}\text { Fat } \\
(\mathrm{g})\end{array}$ & $\begin{array}{l}\text { Carbohydrate } \\
(\mathrm{g})\end{array}$ & $\begin{array}{l}\text { Protein } \\
(\mathrm{g})\end{array}$ & $\begin{array}{l}\text { Energy } \\
(\mathrm{kcal})\end{array}$ \\
\hline Dean's Whipping Cream & 66 & 0 & 0 & 594 \\
Eddy's Grand Vanilla Ice Cream & 11 & 24 & 3 & 202 \\
Amazing Egg & 0 & 1 & 6 & 28 \\
Total & 77 & 25 & 9 & 824 \\
\hline
\end{tabular}

All ingredients were placed in a blender and mixed. Fat $=83.5 \%$; Carbohydrate $=12.0 \%$; Protein $=4.4 \%$. Each shake $=0.354 \mathrm{~L}(12 \mathrm{oz})$
Siemens ADVIA 1800, and low-density lipoprotein cholesterol (LDL-C) was calculated by the Friedewald equation: LDL-C $=($ Total Cholesterol $)-($ HDL-C $)-($ very lowdensity lipoprotein (triglycerides/5)) [33].

\section{Cell-free DGAT1 assay}

A cell-free DGAT1 assay was established using a human small intestinal microsomal preparation (BD Biosciences) as the enzyme source, and dioleoyl glycerol and palmitoleoyl Coenzyme A (CoA) as substrates (Sigma). Dioleoyl glycerol was dissolved in DMSO and diluted to $600 \mu \mathrm{M}$ with $175 \mathrm{mM}$ Tris- $\mathrm{HCl}$ and $100 \mathrm{mM} \mathrm{MgCl}$ (Tris/ $\mathrm{MgCl}_{2}$ ) buffer. Palmitoleoyl CoA was dissolved in $1.5 \%$ acetone water solution (Fisher Scientific) to $150 \mu \mathrm{M}$. Microsomes were diluted to $25 \mu \mathrm{g} / \mathrm{mL}$ with $3.5 \mathrm{mg} / \mathrm{mL}$ BSA in Tris $\mathrm{MgCl}_{2}$ buffer. To a $1.5 \mathrm{~mL}$ tube, $67 \mu \mathrm{L}$ of each palmitoleoyl CoA s and dioleoyl glycerol solutions (1:1 ratio) were added and the reaction was initiated by the addition of $67 \mu \mathrm{L}$ of microsomes. The reaction was incubated in a $37^{\circ} \mathrm{C}$ water bath for $60 \mathrm{~min}$. The reaction was stopped by the addition of $1 \mathrm{~mL}$ of extraction solvent (isopropanol:dichloromethane $(1: 1 \mathrm{v} / \mathrm{v})$ with $2.4 \%$ formic acid) containing $1 \mu \mathrm{g} / \mathrm{mL}$ internal standard (glyceryl triolein, Sigma) to each tube and mixed by vortexing. The tubes were centrifuged at $10,000 \mathrm{Xg}$ for $3 \mathrm{~min} .500 \mu \mathrm{L}$ of the bottom phase was filtered through a Millex-HV syringe driven filter unit with tube outlet (PVDF @ $0.45 \mu \mathrm{m}$, Millipore) and transferred to LC-MS vials (12x32 mm glass screw neck, preslit cap \& PTFE/silicone septa, Waters). Phytochemicals (Sigma), botanical extracts and positive control were diluted in DMSO and added to the reaction with the substrates at the desired concentration. The DGAT1 inhibitor A922500 (Tocris) was used as positive control at a concentration of $40 \mathrm{nM}$.

\section{LC-MS analysis}

Refer to Table 3 for the mobile phase program. Solvent A: $0.1 \%$ ammonium acetate in water; Solvent B: $0.1 \%$ acetic acid in acetonitrile; Solvent C: $0.1 \%$ acetic acid in isopropanol; all solvents were from Fisher Scientific. Injection volume: $10 \mu \mathrm{L}$. Column: Acquity $\mathrm{BEH} \mathrm{C} 18$ $1.7 \mu \mathrm{m}, 2.1 \times 50 \mathrm{~mm}$. Effluent from the column was directed to the electrospray source of the mass spectrometer. Electrospray conditions: positive ion mode; cone voltage: $50 \mathrm{eV}$; desolvation temperature: $450{ }^{\circ} \mathrm{C}$; source temperature: $140{ }^{\circ} \mathrm{C}$; nebulizer gas flow: $800 \mathrm{~L} / \mathrm{h}$; cone gas flow: $10 \mathrm{~L} / \mathrm{h}$. The mass spectrometer was operated at 20,000 resolving power and scans from $\mathrm{m} / \mathrm{z}$ 100-1200 were acquired with a cycle time of $0.25 \mathrm{~s}$. Selected ion chromatograms were plotted for the following: $\mathrm{m} / \mathrm{z} 875$ representing the ammoniated molecular ion for triacylglycerol reaction product containing 2 oleic acid and 1 palmitoleic acid moieties (C18:1/C18:1/C16:1); m/z 903 for the ammoniated molecular ion of glyceryl triolein 


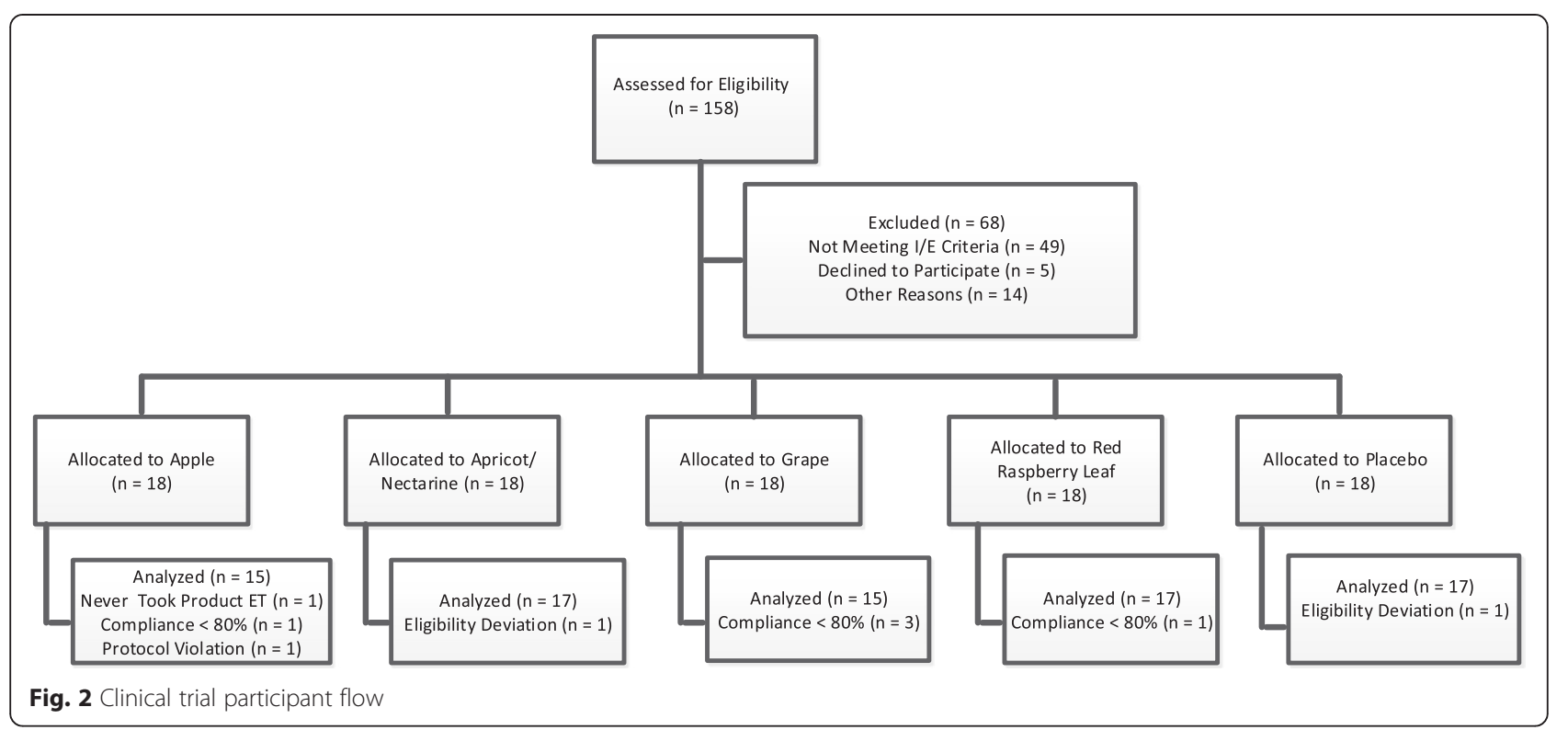

(C18:1/C18:1/C18:1) internal standard. Quantification was determined based on area counts of the product relative to the internal standard.

\section{Cellular DGAT1 assay}

Three different cell lines, human colorectal (HT-29), human embryonic kidney (HEK293H) and human hepatic (HEPG2) were screened for the presence of both DGAT1 and DGAT2 protein. The HEK $293 \mathrm{H}$ cell line contained DGAT1 and little to no DGAT2 protein (Additional file 1: Figure S1), therefore, a cellular DGAT1 assay was established in HEK293H cells to measure the synthesis of TG. HEK293 cell line has previously been reported to contain only DGAT1 and not DGAT2, and has been validated as an in vitro model to determine TG synthesis via DGAT1 [34].

The DGAT1 activity was determined by measuring the incorporation of $\left[{ }^{14} \mathrm{C}\right]$-glycerol $(1 \mu \mathrm{Ci} / \mathrm{mL}$, Perkin-Elmer $)$ into $\left[{ }^{14} \mathrm{C}\right]$-TG during a $5 \mathrm{~h}$ incubation with $0.3 \mathrm{mM}$ oleic acid/BSA in HEK293H cells. Cells were plated in 12-well culture plates at $45,000 / \mathrm{cm}^{2}$, high glucose Dulbecco modified eagle medium (DMEM) supplemented with $10 \%$ (v/v) fetal bovine serum (HyClone), $100 \mathrm{U} / \mathrm{mL}$ penicillin and $100 \mu \mathrm{g} / \mathrm{mL}$ streptomycin (Life Technologies) and allowed to adhere overnight in a humidified

Table 3 Liquid chromatography mobile phase program

\begin{tabular}{lclll}
\hline Time (min) & $\begin{array}{c}\text { Flow rate } \\
(\mathrm{mL} / \mathrm{min})\end{array}$ & Solvent A (\%) & Solvent B (\%) & Solvent C (\%) \\
\hline 0 & 0.4 & 50 & 50 & 0 \\
5 & 0.4 & 0 & 50 & 50 \\
7 & 0.4 & 0 & 50 & 50 \\
8 & 0.4 & 50 & 50 & 0 \\
10 & 0.4 & 50 & 50 & 0 \\
\hline
\end{tabular}

atmosphere with $5 \% \mathrm{CO}_{2}$ at $37{ }^{\circ} \mathrm{C}$. Medium was then changed to serum-free DMEM, and vehicle, positive control (A922500) or botanical extracts were added and pre-incubated with the cells for $30 \mathrm{~min}$ prior to stimulating TG synthesis with oleic acid. After $5 \mathrm{~h}$ of treatment, cells were harvested with cold phosphate buffered saline. Cellular lipids were then extracted with chloroform:methanol $(1: 2 \mathrm{v} / \mathrm{v})$ and centrifuged. The upper phase was aspirated and the organic phase was dried under nitrogen. Lipids were solubilized with a small amount of chloroform containing a TG standard (Perkin-Elmer) and separated by TLC using toluene/ chloroform/methanol mobile phase. Lipid species were identified by iodine vapor and compared to standards. Silica gel spots corresponding to lipid species were scraped into scintillation vials and the incorporated radioactivity was quantified using a MicroBeta TriLux (Perkin-Elmer). All cellular, radiolabeled DGAT1 assay experiments were conducted at Zen-bio Inc. (Research Triangle Park, NC).

\section{Bioassay directed fractionation (BDF) of GE}

GE was prepared at a concentration of $50 \mathrm{mg} / \mathrm{mL}$ in Optima $^{\mathrm{Tm}}$ LCMS grade water and filtered using a Whatman $25 \mathrm{~mm}, 0.45$ micron GD/X syringe filter (Fisher Scientific, Pittsburgh, PA) into $1.5 \mathrm{~mL}$ HPLC autosampler vials for analysis. The injection volume was $10 \mu \mathrm{L} /$ run, providing $500 \mu \mathrm{g}$ of GE extract per injection. Chromatographic separation of phytochemicals in the diluted extract was performed on a Acquity UPLC-H chromatograph equipped with a photodiode array detector (PDA) and XBridge Shield RP18 (5 $\mu \mathrm{m}, 4.6$ x $250 \mathrm{~mm}$ ) column (Waters Corp, Milford, MA). The mobile phase solutions used for gradient separation were prepared with Optima ${ }^{\mathrm{TM}}$ 
LCMS grade solvents (Fisher Scientific, Pittsburgh, PA) as follows: A, $0.1 \%$ acetic acid in water and B, $0.1 \%$ acetic acid in acetonitrile. The mobile phase gradient (A:B), at ambient temperature and a flow rate of $0.8 \mathrm{~mL} / \mathrm{min}$, was initially set at 95:5 and linearly changed to 0:100 from 0 to $30 \mathrm{~min}$, held for $2 \mathrm{~min}$, and then returned to initial conditions at $32.1 \mathrm{~min}$ and held until $35 \mathrm{~min}$. UV-visible data were acquired from $210-800 \mathrm{~nm}$ at a $1.2 \mathrm{~nm}$ resolution using a Waters Acquity PDA eLambda detector.

The effluent was split 10:1 after the PDA detector, with the majority going to a fraction collector configured for 96 well plates with $2 \mathrm{~mL}$ well volume. Fractions were collected at $20 \mathrm{~s}$ intervals for $32 \mathrm{~min}$. A total of 4 injections per collection plate was performed, providing approximately $1.8 \mathrm{mg}$ of GE extract per plate. The plates were frozen at $-80{ }^{\circ} \mathrm{C}$ overnight, and the solvent subsequently removed by freeze drying. The dried sample plates were sealed and stored dry at $-20{ }^{\circ} \mathrm{C}$ until assayed in the cell-free DGAT1 assay.

The remaining effluent was directed to a Synapt G2 QTOF mass spectrometer (Waters Corp, Milford, MA) equipped with an electrospray ion source and operated at $25 \mathrm{~V}$ cone voltage. Accurate mass spectra were collected in separate runs for both positive and negative ions, using Leu-enkephalin as a mass marker.
Data were collected from $\mathrm{m} / \mathrm{z} 100-1200$ at $0.5 \mathrm{~s} /$ spectrum. Alternating spectra were collected at $0 \mathrm{eV}$ and $20 \mathrm{eV}$ collision energy per cycle, with argon used as the collision gas in the transfer cell ( $\mathrm{MS}^{e}$ mode). Mass spectra, UV spectra and bioassay responses for fractions were time aligned for identification of phytochemicals corresponding to the observed DGAT1 enzyme inhibition.

\section{Statistical methods}

Dose response curves for the cell-free DGAT1 assay were fitted with a $\log$ (inhibitor) vs. response, variable slope (four parameters) equation. Cellular DGAT1 assay data is shown as mean \pm standard error of mean (SEM) and was analyzed by two-way ANOVA with Bonferroni's multiple comparison test. The primary outcome variable, serum TG level, is presented as mean \pm SEM of baseline (fasting) subtracted change in serum TG after the HFM challenge. Area under the curve (AUC) was determined using the trapezoidal method. Comparisons between groups were made using unpaired $t$-test with Welch's correction. A significant effect of investigational product was defined as $P<0.05$. All statistical analyses were done using Prism-Graph Pad Software (San Diego, CA).

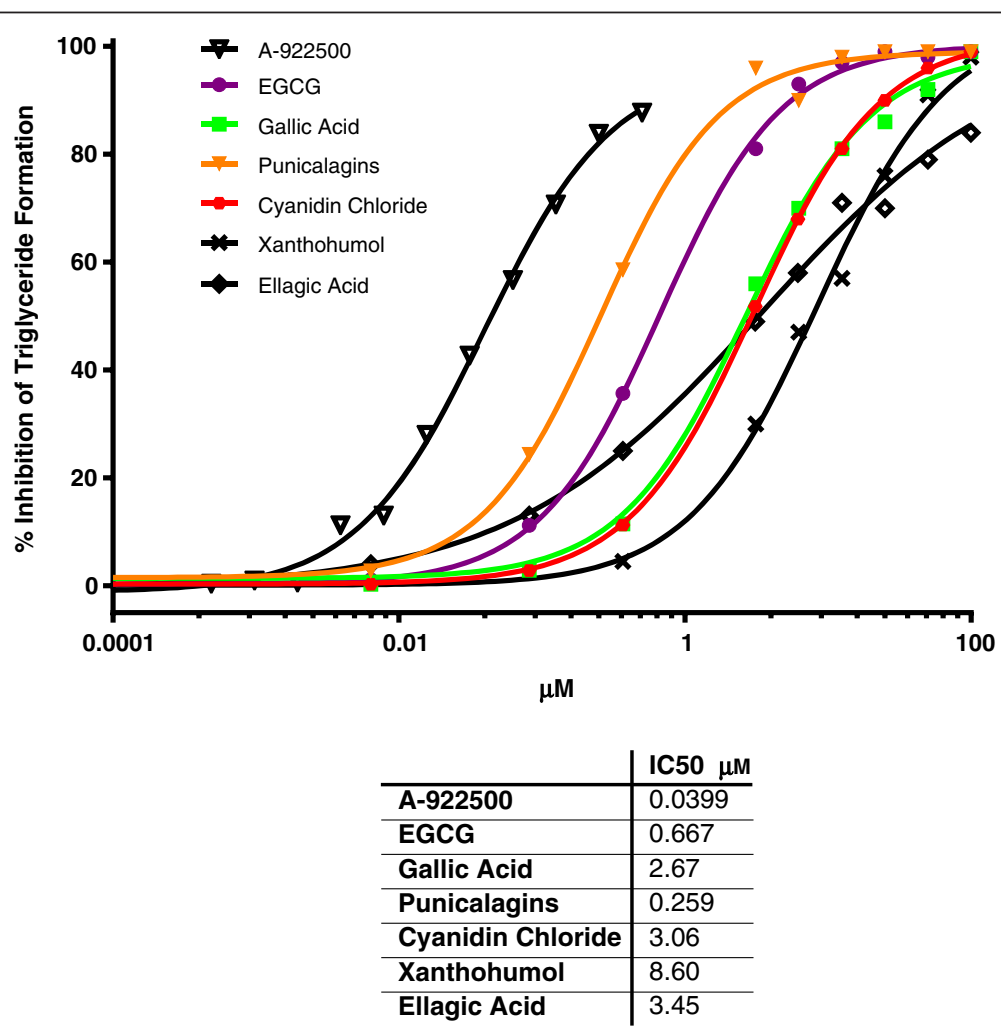

Fig. 3 Percent DGAT1 enzyme inhibition and IC50 values for single phytochemicals in the cell-free assay. Twenty individual phytochemicals were screened through the cell-free DGAT1 enzyme assay. Six of the twenty phytochemicals were dose dependent inhibitors of DGAT1 enzyme activity (IC50 ranged from 0.667 to $8.60 \mu \mathrm{M}$, compared to A-922500 =40nM) and all were phenolic acids or polyphenols. Results are the mean of duplicates 


\section{Results}

In vitro DGAT1 screening

We first screened a panel of 20 phytochemicals, mostly polyphenols and phenolic acids (Apigenin,
Astilbin, Catechin, Cyanidin Chloride, Dihydrokaempferol, Epigallocatechin Gallate (EGCG), Ellagic Acid, Formononetin, Gallic Acid, Guggulsterone, Kaempferol, Icariin, Luteolin, Naringenin, Paeoniflorin, Punicalagins,
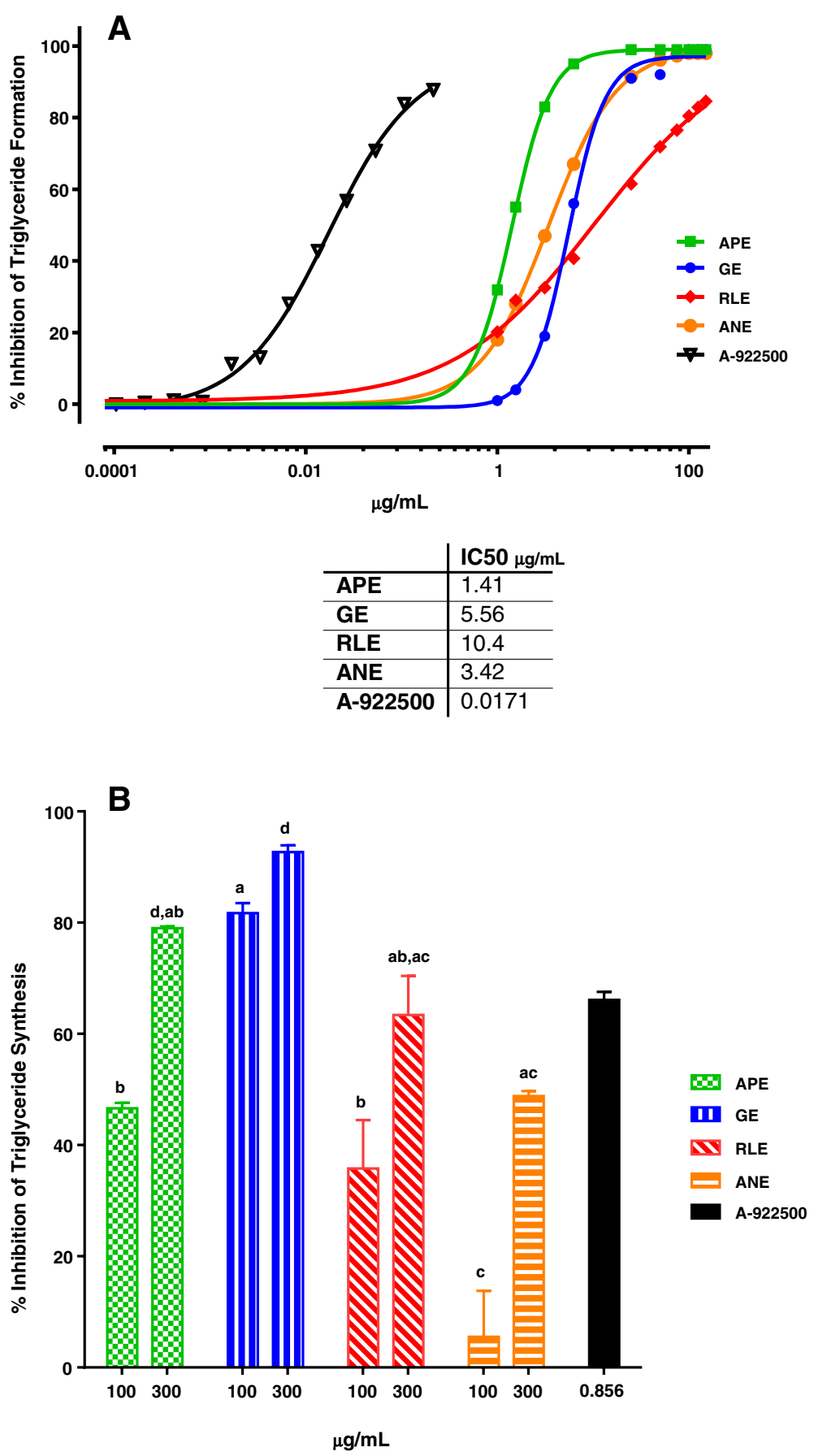

Fig. 4 Percent DGAT1 enzyme inhibition and IC50 values for the four lead botanical extracts. a APE, GE, RLE and ANE exhibited dose responsive inhibition of DGAT1 enzyme activity in the cell-free assay. The IC50 values ranged from 1.41 to $10.4 \mu \mathrm{g} / \mathrm{mL}$ and $17.1 \mathrm{ng} / \mathrm{mL}$ for A-922500. Results are the mean of triplicates. $\mathbf{b}$ The cellular DGAT1 assay was comprised of adding $\left[{ }^{14} \mathrm{C}\right]$-glycerol to label newly synthesized TG and $0.3 \mathrm{mM}$ oleic acid/BSA to stimulate DGAT1 activity. All botanical extracts and A-922500 inhibited oleic acid induced DGAT1 enzyme activity as measured by ${ }^{14} \mathrm{C}$ label TG levels. GE was statistically more potent than APE, RLE and ANE, defined as greatest inhibition at the lowest dose $(100 \mu \mathrm{g} / \mathrm{mL})$ (Two-way ANOVA with Bonferroni's multiple comparisons test; $P<0.001)$. Result are the mean \pm SEM $(n=3)$. Different letters, within each dose, indicate statistically significant 
Orientin, Sparteine, Taxifolin and trans-Resveratrol) in the cell-free DGAT1 assay to aid in the selection of prospective botanical extracts for screening. Phytochemicals with $\geq 50 \%$ DGAT1 inhibition at $50 \mu \mathrm{M}$ were further examined in titration experiments. Six phytochemicals were dose dependent inhibitors of DGAT1 enzyme activity (Fig. 3) and all were polyphenols or phenolic acids (data not shown for remaining fourteen phytochemicals). The IC50 values ranged from 0.667 to $8.60 \mu \mathrm{M}$ compared to 39.9 $\mathrm{nM}$ for the synthetic inhibitor A922500.

Botanical extracts from an internal, proprietary botanical extract library were selected based on their predicted presence of the polyphenolic inhibitors presented in Fig. 3, and screened through the cell-free DGAT1 assay. Four lead botanical extracts emerged from the library screening (Fig. 4): 1) apple peel extract (APE); 2) grape extract (GE); 3) red raspberry leaf extract (RLE); 4) apri$\mathrm{cot} /$ nectarine extract (ANE) with IC50 values in cell-free assay of $1.4,5.6,10.4$ and $3.4 \mu \mathrm{g} / \mathrm{mL}$, respectively (Fig. 4a). In the cellular DGAT1 assay, all extracts inhibited TG synthesis $\geq 50 \%$ at 100 and/or $300 \mu \mathrm{g} / \mathrm{mL}$. While all botanical extracts were effective in this cellular assay, the GE was the most potent (greatest inhibition at the lowest dose) with APE and RLE having equally potency, and ANE the least. (Fig. $4 \mathrm{~b}, P<0.001$ ).

\section{Clinical trial}

Participant flow through the study protocol is outlined in Fig. 2. Ninety participants were randomized into 5 test groups: Placebo, APE, GE, RLE and ANE $(n=18 /$ group). Eighty-one participants completed the trial per protocol and Table 4 shows the day 1 characteristics of these participants. There were no significant differences in age, body mass index (BMI) or fasting, TC, LDL-C, HDL-C or TG at baseline between groups. Gender was not balanced across the test groups.

No placebo or investigational product related changes were observed in vital signs, serum chemistry or hematology parameters (data not shown). Nineteen study participants experienced an adverse event (AE) considered to be potentially related to placebo or investigational product. All of these $\mathrm{AE}$ were graded as mild and did not impact study participation (Additional file 2: Table S1). Diarrhea, potentially related to fat malabsorption, was not reported by any subject.

There was no significant difference across all groups in the baseline (fasting) subtracted change in serum TG AUC after the HFM challenge at day 1 (data not shown). After seven days of placebo or investigational products, only the GE significantly impacted the baseline subtracted change in serum TG levels following the HFM challenge compared to placebo. GE significantly reduced the $2 \mathrm{~h}(P=0.014)$ and $4 \mathrm{~h}(P=0.029)$ baseline subtracted change in serum TG compared to placebo (Fig. 5a). This translated into a significant reduction in the AUC (Fig. 5b; $P=0.021$ ). No significant differences in fasting TC, LDL-C, HDL-C or TG were seen after seven days of placebo or investigational product (Table 4).

\section{Bioassay-directed fractionation (BDF) of GE}

In efforts to identify potential bioactive phytochemicals from GE, we chromatographically fractionated GE into a 96-well plate. Fractions were subsequently screened through the cell-free DGAT1 enzyme assay. Chromatographic characterization of GE revealed a large number of closely eluting components containing primarily

Table 4 Day 1 and day 7 characteristics of participants completing the trial per protocol

\begin{tabular}{|c|c|c|c|c|c|c|}
\hline Characteristics & Test Day & Placebo & APE & GE & RLE & ANE \\
\hline N (Male/Female) & & $17(9 / 8)$ & $15(7 / 8)$ & $15(6 / 9)$ & $17(6 / 11)$ & $17(11 / 6)$ \\
\hline Age (years) & & $46.7 \pm 9.9$ & $47.0 \pm 9.3$ & $52.7 \pm 12.6$ & $46.8 \pm 8.2$ & $48.4 \pm 9.0$ \\
\hline \multirow[t]{2}{*}{ Body Weight (kg) } & 1 & $90.8 \pm 14.7$ & $91.0 \pm 10.4$ & $88.3 \pm 15.1$ & $86.3 \pm 13.6$ & $87.9 \pm 9.7$ \\
\hline & 7 & $90.8 \pm 14.7$ & $91.1 \pm 10.7$ & $88.0 \pm 15.3$ & $86.3 \pm 13.6$ & $88.0 \pm 9.6$ \\
\hline \multirow[t]{2}{*}{ BMI } & 1 & $30.2 \pm 3.9$ & $32.0 \pm 1.8$ & $30.8 \pm 2.9$ & $30.8 \pm 3.5$ & $30.4 \pm 3.5$ \\
\hline & 7 & $30.1 \pm 3.9$ & $32.0 \pm 1.9$ & $30.7 \pm 3.0$ & $30.5 \pm 3.4$ & $30.4 \pm 3.5$ \\
\hline \multirow[t]{2}{*}{ Total Cholesterol (mg/dL) } & 1 & $206 \pm 41$ & $183 \pm 30$ & $190 \pm 46$ & $196 \pm 34$ & $200 \pm 46$ \\
\hline & 7 & $195 \pm 44$ & $170 \pm 25$ & $175 \pm 35$ & $191 \pm 31$ & $184 \pm 35$ \\
\hline \multirow[t]{2}{*}{$\mathrm{LDL}-\mathrm{C}(\mathrm{mg} / \mathrm{dL})$} & 1 & $135 \pm 42$ & $116 \pm 30$ & $115 \pm 42$ & $123 \pm 34$ & $133 \pm 43$ \\
\hline & 7 & $129 \pm 43$ & $107 \pm 25$ & $105 \pm 29$ & $117 \pm 34$ & $119 \pm 35$ \\
\hline \multirow[t]{2}{*}{$\mathrm{HDL}-\mathrm{C}(\mathrm{mg} / \mathrm{dL})$} & 1 & $50.3 \pm 18.1$ & $51.0 \pm 17.2$ & $58.7 \pm 17.2$ & $57.8 \pm 17.7$ & $50.1 \pm 12.5$ \\
\hline & 7 & $48.2 \pm 19.4$ & $46.3 \pm 13.5$ & $55.4 \pm 19.8$ & $54.8 \pm 19.2$ & $46.8 \pm 11.2$ \\
\hline \multirow[t]{2}{*}{$\mathrm{TG}(\mathrm{mg} / \mathrm{dL})$} & 1 & $97.5 \pm 39.8$ & $96.7 \pm 39.8$ & $101.7 \pm 38.7$ & $102.3 \pm 35.8$ & $111.1 \pm 46.8$ \\
\hline & 7 & $95.8 \pm 36.2$ & $94.7 \pm 26.4$ & $90.3 \pm 23.8$ & $102.1 \pm 57$ & $103.8 \pm 40.4$ \\
\hline
\end{tabular}




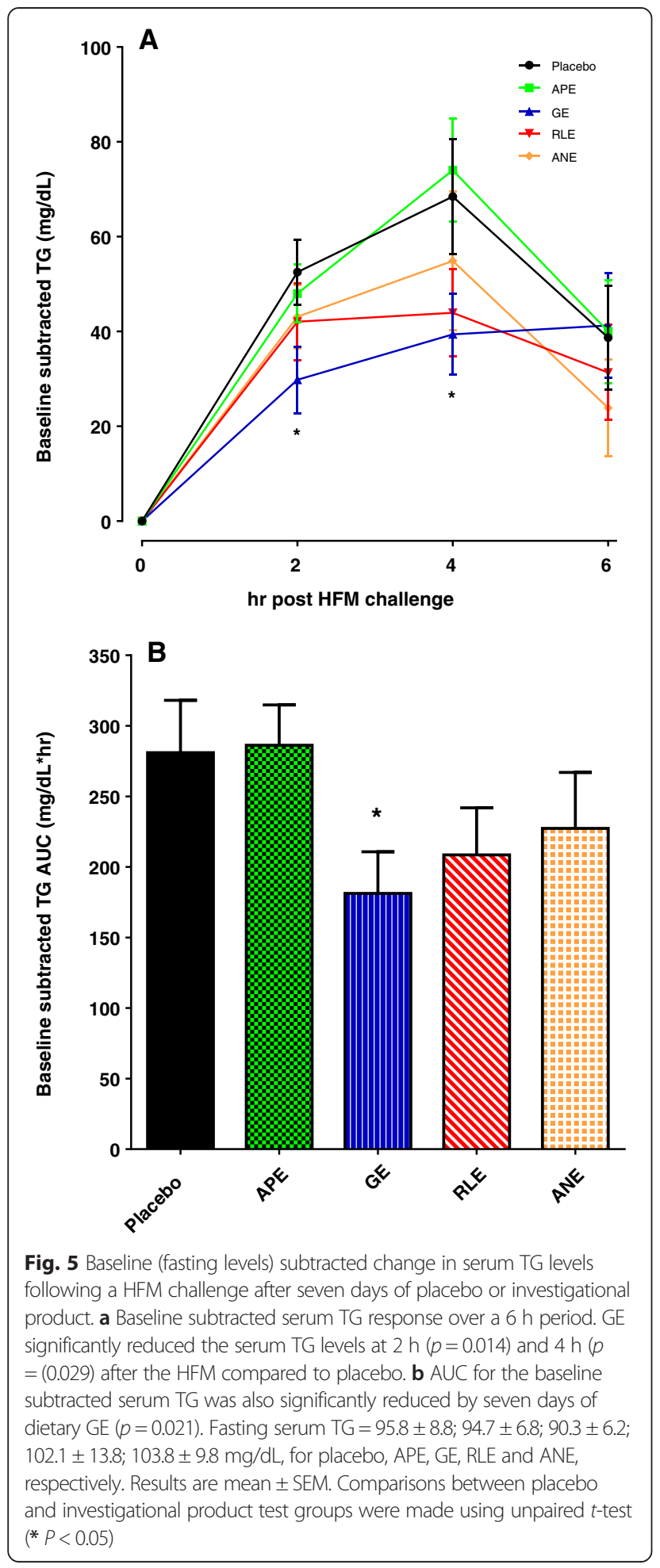

proanthocyanidins, catechins, anthocyanins and other polyphenols based on mass spectral and UV-visible data (Fig. 6a, b). The relative amount of DGAT1 enzyme inhibition (right side $\mathrm{X}$-axis) for the fractions paralleled chromatographic abundance of components in the GE (left side X-axis). These data suggest that there are multiple polyphenols in GE that could be contributing to the inhibition of DGAT1 enzyme activity. Table 5 lists ten polyphenols that were identified based on accurate mass and UV-vis spectra data. Peaks 3-9 (malvidin3 -glucoside, procyanidin $\mathrm{B} 1$, catechin, procyanidin $\mathrm{B} 2$, epicatechin, procyanidin $\mathrm{C} 1$ and syringic acid, respectively) corresponded in retention time with fractions that inhibited DGAT1 enzyme activity by greater than $50 \%$ in the cell-free assay (Fig. 6a, b). While the phytochemicals co-elute at the time corresponding to the observed DGAT1 enzyme inhibition, they were not necessarily solely responsible for the inhibition of that peak. This is due to the fact there are likely many unresolved and unidentified phenolic acids and polyphenols that are co-eluting during the 9-16 min retention time frame. Therefore, this unique mixture, and one single phytochemical, is likely responsible of the observed efficacy.

\section{Discussion}

The circulating TG levels in response to a HFM challenge has been validated in both animal and human studies to be a method of examining intestinal DGAT1 activity [25, 27, 35-38]. Here we report the first demonstration in vitro and in humans that a GE inhibits intestinal DGAT1 as measured by the change in serum TG following a HFM challenge. Seven days of dietary GE resulted in a significant reduction in the serum TG AUC following the HFM compared to placebo. This effect was unique to GE, as no significant efficacy was observed in the three other investigational products (APE, RLE and ANE) examined in this study.

Intestinal DGAT1 plays a major role in the postprandial TG response by regulating enterocyte TG synthesis and secretion [22, 35, 39]. Intestinal DGAT1 is positioned at a site that makes it a good candidate for impacting the postprandial TG response. Pharmacological inhibitors of DGAT1 have been shown to effectively reduce the postprandial TG response to an HFM challenge [36, 37, 40, 41], but not without significant and intolerable gastrointestinal side effects in humans like nausea, diarrhea and vomiting. This indicates that intestinal DGAT1 is a good target to reduce postprandial TG levels. However, the gastrointestinal side effects due to the high selectivity and potency of pharmaceutical DGAT1 inhibitors has limited their full development. Therefore, if dietary interventions could reduce the chronic systemic exposure of postprandial hypertriglyceridemia by modulating, in part, intestinal DGAT1 activity without significant and intolerable gastrointestinal side effects, this could be a potential dietary strategy to improve multiple cardiovascular and metabolic risks linked to postprandial hypertriglyceridemia. 


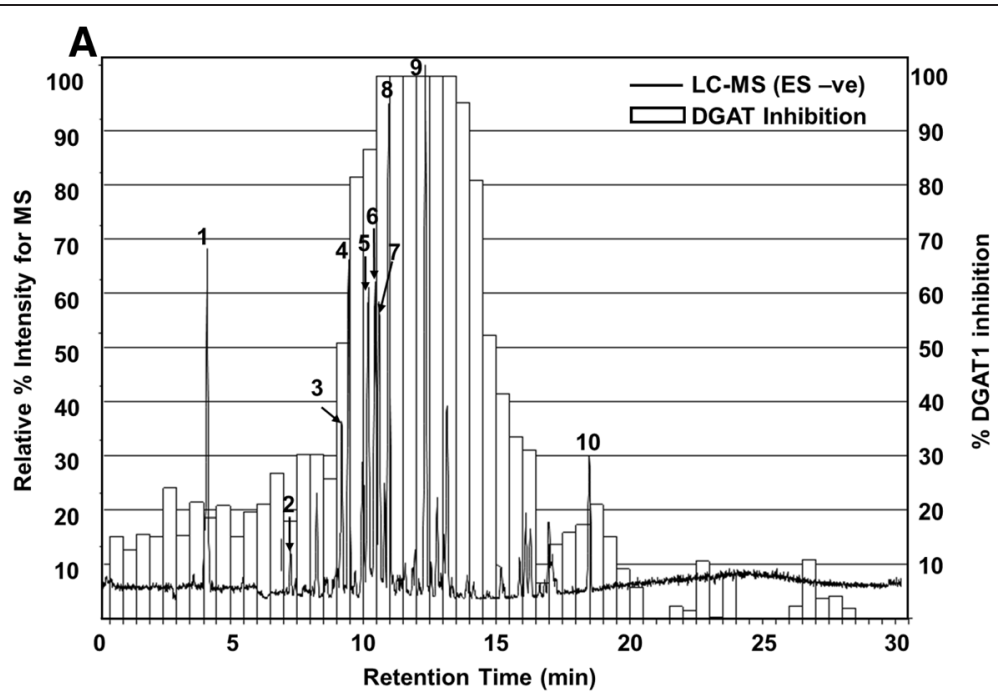

B

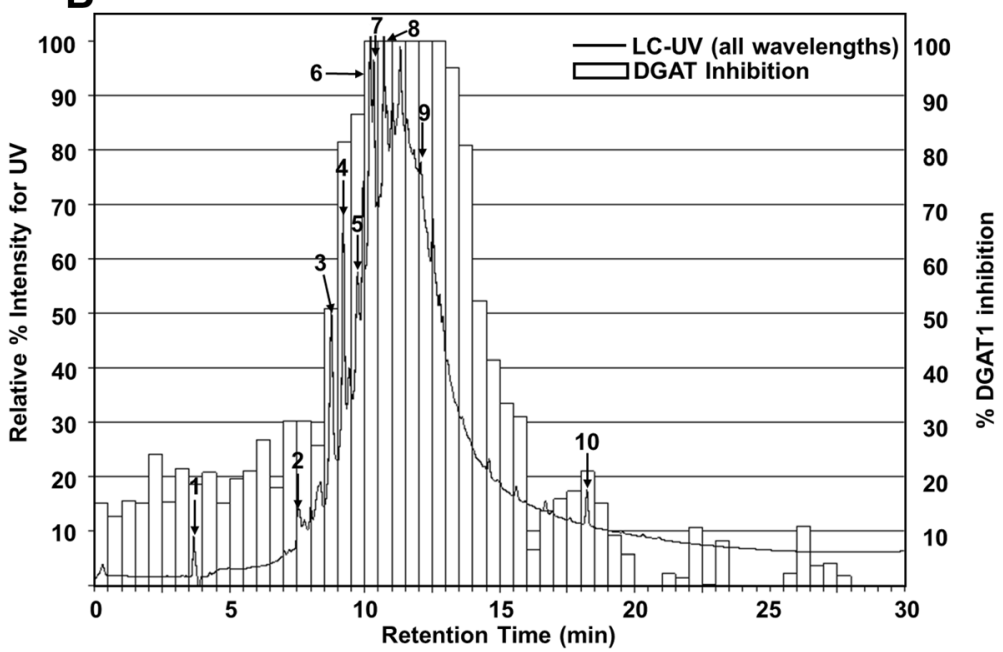

Fig. 6 Cell-free DGAT1 inhibition from chromatographic fractionation of GE with overlay of the corresponding LC-MS and LC-UV chromatograms. a The LC-MS chromatogram was generated using base peak index utility to differentiate major compounds. $\mathbf{b}$ The LC-UV chromatogram represents the sum of all wavelengths to better show the complex mixture and abundance of phytochemicals in the GE extract. DGAT1 enzyme inhibition (right side $x$-axis) correlates with the LC-UV pattern and abundance (left side $x$-axis), showing that multiple phytochemicals in the GE extract are responsible for the observed inhibition. Identities of numbered peaks are given in Table 5

Table 5 Phytochemical class and identified peaks from GE

\begin{tabular}{|c|c|}
\hline $\begin{array}{l}\text { Phytochemical } \\
\text { Class }\end{array}$ & Phytochemical Identity (peak \#) \\
\hline Organic Acids & 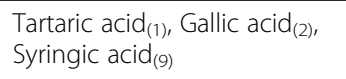 \\
\hline Catechins & Catechin $_{(5)}$, Epicatechin $_{(7)}$ \\
\hline $\begin{array}{l}\text { Oligomeric } \\
\text { Proanthocyanidins }\end{array}$ & $\begin{array}{l}\text { Procyanidin } \mathrm{B} 1_{(4)} \text {, Procyanidin } \\
\mathrm{B}_{(6)}, \text { Procyanidin }-\mathrm{Cl}_{(8)}\end{array}$ \\
\hline Anthocyanins & Malvidin-3-glucoside $(3)$ \\
\hline Flavones & Quercetin $_{(10)}$ \\
\hline
\end{tabular}

Grapes in a variety of forms have been reported to provide multiple cardiovascular health benefits [42, 43]. These health benefits have been associated with numerous mechanisms of action [42, 44, 45], and the unique phytochemical groups present in grapes such as simple phenolics, flavonoids, anthocyanins, stilbenes and proanthocyanidin have been reported to be responsible for these health benefits [42, 46-49]. On a broader clarification, all these phytochemical groups belong to the polyphenol class of phytochemicals. Some of these polyphenols are derived from specific components of the grape (i.e., stilbenes in skin, anthocyanins in flesh or proanthocyanidins in seeds) and are the most important class of bioactive compounds in grapes. Grape is one of 
the richest sources of polyphenols among fruits and over 500 phytochemicals have been identified [50]. Therefore, the wide range of health benefits and pleiotropic effects of grapes and grape products on human health is likely due to the unique phytochemical profile [50-52]. We have identify several of these polyphenols as potential bioactives inhibiting DGAT1 enzyme activity.

The GE used in this study was a highly concentrated extract (8000:1 extraction ratio) of grape pulp, skin and seeds that is $75 \%$ and $50 \%$ by weight polyphenols and oligomeric proanthocyanidins (OPC), respectively (see Table 1). The BDF data suggests there are multiple types of polyphenols (e.g., proanthocyanidins, catechins and anthocyanins) that are contributing to DGAT1 enzyme inhibition (Fig. 6 and Table 5). Interestingly, the APE, RLE and ANE also contain polyphenols, yet no significant in vivo efficacy was observed. This is likely due to various factors including the different types, absolute amounts and mutual ratios of polyphenols as they are typically more active when existing as a mixture, rather than in individual forms [53]. Other factors such as intestinal absorption, hydrolysis by small intestine enzymes and/or bacterial modification could have influenced the potential in vivo efficacy of the polyphenols [54-56]. Based on the compositional information in Table 5 and our BDF data, it is likely that the unique profile, ratio and amounts of anthocyanin metabolites and OPC in the GE are involved with the observed in vivo effect, as these polyphenols are abundant in grapes but not in the other three botanical extracts.

We report several lines of evidence supporting the idea that GE lowers postprandial TG, in part, via inhibition of intestinal DGAT1. To support this MOA, we used a cell-free DGAT1 enzyme screening assay in which DGAT1 activity was derived from human intestinal microsomes, and then employed $\mathrm{MgCl}_{2}$ to selectively inhibit any DGAT2 activity present. Secondary confirmation of inhibition was provided by using a cellbased assay in which the cellular model did not express DGAT2 [34]. In vitro experiments therefore reflect only inhibition against DGAT1 enzyme activity and not DGAT2. This is relevant since only DGAT1, but not DGAT2 enzyme, has been reported to be present in human small intestine $[39,57,58]$. Finally, clinical assessment of functional activity relied on circulating TG levels in response to a HFM challenge which is a validated model and biomarker to examine intestinal DGAT1 enzyme activity. In this model, pharmacological inhibition of DGAT1 in both rodents and humans results in reduced AUC of circulating TG and increased time to peak plasma TG following a HFM challenge [27, 35, 37, 38, 41]. This postprandial TG profile is similar to results observed in our clinical trial.
It is possible that additional mechanisms and targets could have been affected by the GE that in part contributes to the reduction in the HFM induced hypertriglyceridemia. Mechanisms involved in controlling the rate of gastric emptying may have been impacted via gut derived hormones [59] and/or directly or indirectly by inhibition of intestinal DGAT1 activity [35]. GE may have inhibited other intestinal TG assimilation acyltransferase enzymes (i.e., MGAT1, 2) or metabolic pathways that occur prior to the DGAT1 reaction (i.e., luminal absorption and enterocyte transport). In addition, an effect on chylomicron assembly, transport into the circulation and systemic catabolism cannot be completely ruled out.

\section{Conclusion}

Our research has led to the identification of a dietary GE that inhibits DGAT1 activity in vitro and is the first clinical study to show a reduction in postprandial TG response to a HFM in overweight and obese humans at a dose that would be difficult to achieve in the diet with whole grapes. These data suggest that a dietary GE has the potential to provide safe and significant attenuation of high fat diet driven hypertriglyceridemia via a mechanism that may include inhibition of intestinal DGAT1 activity. These results merit further clinical investigation and characterization of bioactive phytochemicals unique to the whole GE. Therefore, we are conducting a longer term clinical study with the GE in a more diverse population and are further characterizing potential bioactives.

\section{Additional files}

Additional file 1: Figure S1. Western blot analysis for the presence of both DGAT1 and DGAT2 protein in human colorectal cell line (HT-29), human embryonic kidney (HEK293H) and human hepatic cell line (HEPG2). (PDF $225 \mathrm{~kb}$ )

Additional file 2: Table S1. Reported adverse events that were potentially related to placebo or investigation products. (PDF $87 \mathrm{~kb}$ )

\section{Abbreviations}

APE: Apple peel extract; ANE: Apricot/Nectarine extract; AUC: Area under the curve; DGAT1: Diacylglyceride acyltransferase 1; GE: Grape extract; HFM: High fat meal; IC50: Inhibition concentration of $50 \%$; RLE: Red raspberry leaf extract; TG: Triglyceride.

\section{Competing interests}

All studies were fully funded by Amway R\&D. Rodney A. Velliquette, Kerry Grann, Stephen R. Missler, Chun Hu, Kevin W. Gellenbeck, Jeffrey D. Scholten, R. Keith Randolph are employees of Amway R\&D. Jennifer Patterson was an employee of Amway R\&D during the conduction of these studies, but is not a current employee and currently has no conflict of interest.

\section{Authors' contributions}

RAV, KG, JDS, and RKR designed research; RAV, KG, JP and SRM conducted research; RAV analyzed data; $\mathrm{CH}$ and KWG provided essential materials; RAV and KG wrote paper; RAV had primary responsibility for final content. All authors have read and approved the final manuscript. 


\section{Author details}

${ }^{1}$ Department of Analytical Sciences, Amway R\&D, 7575 Fulton St., Building 50-2D, Ada, Ml 49355, USA. Nutrition Product Development, Food, Beverages and Chewables, Amway R\&D, Ada, MI 49355, USA. ${ }^{3}$ Nutrition Product Development, Supplements, Nutrilite Health Institute, Buena Park, CA 90622, USA.

\section{Received: 21 May 2015 Accepted: 29 July 2015}

\section{Published online: 06 August 2015}

\section{References}

1. Swinburn BA, Sacks G, Hall KD, McPherson K, Finegood DT, Moodie ML, et al. The global obesity pandemic: shaped by global drivers and local environments. Lancet. 2011;378:804-14.

2. Chun OK, Chung SJ, Song WO. Estimated dietary flavonoid intake and major food sources of U.S. adults. J Nutr. 2007;137:1244-52.

3. Miller M, Stone NJ, Ballantyne C, Bittner V, Criqui MH, Ginsberg HN, et a Triglycerides and cardiovascular disease: a scientific statement from the American Heart Association. Circulation. 2011;123:2292-333.

4. Boren J, Matikainen N, Adiels M, Taskinen MR. Postprandia hypertriglyceridemia as a coronary risk factor. Clin Chim Acta. 2014:431:131-42.

5. Katsanos CS. Clinical considerations and mechanistic determinants of postprandial lipemia in older adults. Adv Nutr. 2014;5:226-34.

6. Chan DC, Pang J, Romic G, Watts GF. Postprandial hypertriglyceridemia and cardiovascular disease: current and future therapies. Curr Atheroscler Rep. 2013;15:309

7. Zilversmit DB. Atherogenic nature of triglycerides, postprandial lipidemia, and triglyceride-rich remnant lipoproteins. Clin Chem. 1995;41:153-8.

8. Zilversmit DB. Atherogenesis: a postprandial phenomenon. Circulation. 1979;60:473-85.

9. Bansal S, Buring JE, Rifai N, Mora S, Sacks FM, Ridker PM. Fasting compared with nonfasting triglycerides and risk of cardiovascular events in women. JAMA. 2007;298:309-16

10. Cohn JS. Are we ready for a prospective study to investigate the role of chylomicrons in cardiovascular disease? Atheroscler Suppl. 2008;9:15-8.

11. Redgrave TG. Chylomicrons in disease-future challenges Invited keynote address. Atheroscler Suppl. 2008:9:3-6.

12. DeVita RJ, Pinto S. Current status of the research and development of diacylglycerol O-acyltransferase 1 (DGAT1) inhibitors. J Med Chem. 2013;56:9820-5.

13. Nordestgaard BG, Benn M, Schnohr P, Tybjaerg-Hansen A. Nonfasting triglycerides and risk of myocardial infarction, ischemic heart disease, and death in men and women. JAMA. 2007;298:299-308.

14. Sasase T, Morinaga H, Yamamoto H, Ogawa N, Matsui K, Miyajima K, et al. Increased fat absorption and impaired fat clearance cause postprandial hypertriglyceridemia in Spontaneously Diabetic Torii rat. Diabetes Res Clin Pract. 2007;78:8-15.

15. Ceriello A, Quagliaro L, Piconi L, Assaloni R, Da Ros R, Maier A, et al. Effect of postprandial hypertriglyceridemia and hyperglycemia on circulating adhesion molecules and oxidative stress generation and the possible role of simvastatin treatment. Diabetes. 2004:53:701-10.

16. Bae JH, Schwemmer M, Lee IK, Lee HJ, Park KR, Kim KY, et al. Postprandial hypertriglyceridemia-induced endothelial dysfunction in healthy subjects is independent of lipid oxidation. Int J Cardiol. 2003;87:259-67.

17. Bae JH, Bassenge E, Kim KB, Kim YN, Kim KS, Lee HJ, et al. Postprandial hypertriglyceridemia impairs endothelial function by enhanced oxidant stress. Atherosclerosis. 2001;155:517-23.

18. Teno $S$, Uto $Y$, Nagashima $H$, Endoh $Y$, Iwamoto $Y$, Omori $Y$, et al. Association of postprandial hypertriglyceridemia and carotid intima-media thickness in patients with type 2 diabetes. Diabetes Care. 2000;23:1401-6.

19. Mitsuguchi $Y$, Ito T, Ohwada K. Pathologic findings in rabbit models of hereditary hypertriglyceridemia and hereditary postprandial hypertriglyceridemia. Comp Med. 2008;58:465-80.

20. Botham KM, Wheeler-Jones CP. Postprandial lipoproteins and the molecular regulation of vascular homeostasis. Prog Lipid Res. 2013;52:446-64.

21. Schwander F, Kopf-Bolanz KA, Buri C, Portmann R, Egger L, Chollet M, et al. A Dose-response Strategy Reveals Differences between Normal-Weight and Obese Men in Their Metabolic and Inflammatory Responses to a High-Fat Meal. J Nutr. 2014;144:1517-23.
22. Yen $\mathrm{CL}$, Stone SJ, Koliwad S, Harris C, Farese Jr RV. Thematic review series: glycerolipids. DGAT enzymes and triacylglycerol biosynthesis. J Lipid Res. 2008;49:2283-301.

23. Smith SJ, Cases S, Jensen DR, Chen HC, Sande E, Tow B, et al. Obesity resistance and multiple mechanisms of triglyceride synthesis in mice lacking Dgat. Nat Genet. 2000;25:87-90.

24. Ables GP, Yang KJ, Vogel S, Hernandez-Ono A, Yu S, Yuen JJ, et al. Intestinal DGAT1 deficiency reduces postprandial triglyceride and retinyl ester excursions by inhibiting chylomicron secretion and delaying gastric emptying. J Lipid Res. 2012:53:2364-79.

25. Lee B, Fast AM, Zhu J, Cheng JX, Buhman KK. Intestine-specific expression of acyl CoA:diacylglycerol acyltransferase 1 reverses resistance to dietinduced hepatic steatosis and obesity in Dgat1-/- mice. J Lipid Res. 2010;51:1770-80.

26. Birch AM, Buckett LK, Turnbull AV. DGAT1 inhibitors as anti-obesity and antidiabetic agents. Curr Opin Drug Discov Devel. 2010;13:489-96.

27. Yeh VS, Beno DW, Brodjian S, Brune ME, Cullen SC, Dayton BD, et al. Identification and preliminary characterization of a potent, safe, and orally efficacious inhibitor of acyl-CoA:diacylglycerol acyltransferase 1. J Med Chem. 2012;55:1751-7.

28. Cheng D, lqual J, Devenny J, Chu CH, Chen L, Dong J, et al. Acylation of acylglycerols by acyl coenzyme A:diacylglycerol acyltransferase 1 (DGAT1). Functional importance of DGAT1 in the intestinal fat absorption. J Biol Chem. 2008:283:29802-11.

29. Schober G, Arnold M, Birtles S, Buckett LK, Pacheco-Lopez G, Turnbull AV, et al. Diacylglycerol acyltransferase-1 inhibition enhances intestinal fatty acid oxidation and reduces energy intake in rats. J Lipid Res. 2013;54:1369-84.

30. Langhans W, Leitner C, Arnold M. Dietary fat sensing via fatty acid oxidation in enterocytes: possible role in the control of eating. Am J Physiol Regul Integr Comp Physiol. 2011;300:R554-65.

31. Lin HV, Chen D, Shen Z, Zhu L, Ouyang X, Vongs A, et al. Diacylglycerol acyltransferase-1 (DGAT1) inhibition perturbs postprandial gut hormone release. PLoS One. 2013;8:e54480.

32. Kolovou GD, Mikhailidis DP, Kovar J, Lairon D, Nordestgaard BG, Ooi TC, et al. Assessment and clinical relevance of non-fasting and postprandial triglycerides: an expert panel statement. Curr Vasc Pharmacol. 2011;9:258-70.

33. Friedewald WT, Levy RI, Fredrickson DS. Estimation of the concentration of low-density lipoprotein cholesterol in plasma, without use of the preparative ultracentrifuge. Clin Chem. 1972;18:499-502.

34. Qi J, Lang W, Giardino E, Caldwell GW, Smith C, Minor LK, et al. Highcontent assays for evaluating cellular and hepatic diacylglycerol acyltransferase activity. J Lipid Res. 2010;51:3559-67.

35. Maciejewski BS, LaPerle JL, Chen D, Ghosh A, Zavadoski WJ, McDonald TS, et al. Pharmacological inhibition to examine the role of DGAT1 in dietary lipid absorption in rodents and humans. Am J Physiol Gastrointest Liver Physiol. 2013;304:G958-69.

36. Denison H, Nilsson C, Lofgren L, Himmelmann A, Martensson G, Knutsson $M$, et al. Diacylglycerol acyltransferase 1 inhibition with AZD7687 alters lipid handling and hormone secretion in the gut with intolerable side effects: a randomized clinical trial. Diabetes Obes Metab. 2014;16:334-43.

37. Denison H, Nilsson C, Kujacic M, Lofgren L, Karlsson C, Knutsson M, et al. Proof of mechanism for the DGAT1 inhibitor AZD7687: results from a firsttime-in-human single-dose study. Diabetes Obes Metab. 2013;15:136-43.

38. Cao J, Zhou Y, Peng H, Huang X, Stahler S, Suri V, et al. Targeting AcylCoA:diacylglycerol acyltransferase 1 (DGAT1) with small molecule inhibitors for the treatment of metabolic diseases. J Biol Chem. 2011;286:41838-51.

39. Hiramine Y, Tanabe T. Characterization of acyl-coenzyme A:diacylglycerol acyltransferase (DGAT) enzyme of human small intestine. J Physiol Biochem. 2011;67:259-64.

40. Serrano-Wu MH, Coppola GM, Gong Y, Neubert AD, Chatelain R, Clairmont KB, et al. Intestinally Targeted Diacylglycerol Acyltransferase 1 (DGAT1) Inhibitors Robustly Suppress Postprandial Triglycerides. ACS Med Chem Lett. 2012;3:411-5.

41. King AJ, Segreti JA, Larson KJ, Souers AJ, Kym PR, Reilly RM, et al. In vivo efficacy of acyl CoA: diacylglycerol acyltransferase (DGAT) 1 inhibition in rodent models of postprandial hyperlipidemia. Eur J Pharmacol. 2010;637:155-61

42. Yang J, Xiao YY. Grape phytochemicals and associated health benefits. Crit Rev Food Sci Nutr. 2013;53:1202-25

43. Dohadwala MM, Vita JA. Grapes and cardiovascular disease. J Nutr. 2009;139:1788S-93. 
44. Joshi SS, Kuszynski CA, Bagchi D. The cellular and molecular basis of health benefits of grape seed proanthocyanidin extract. Curr Pharm Biotechnol. 2001;2:187-200.

45. Lefevre M, Wiles JE, Zhang X, Howard LR, Gupta S, Smith AA, et al. Gene expression microarray analysis of the effects of grape anthocyanins in mice: a test of a hypothesis-generating paradigm. Metabolism. 2008:57:S52-7.

46. Georgiev V, Ananga A, Tsolova V. Recent advances and uses of grape flavonoids as nutraceuticals. Nutrients. 2014:6:391-415.

47. Xia EQ, Deng GF, Guo YJ, Li HB. Biological activities of polyphenols from grapes. Int J Mol Sci. 2010;11:622-46.

48. Yadav M, Jain S, Bhardwaj A, Nagpal R, Puniya M, Tomar R, et al. Biological and medicinal properties of grapes and their bioactive constituents: an update. J Med Food. 2009:12:473-84.

49. Chuang CC, Mclntosh MK. Potential mechanisms by which polyphenol-rich grapes prevent obesity-mediated inflammation and metabolic diseases. Annu Rev Nutr. 2011;31:155-76.

50. Ali K, Maltese F, Choi Y, Verpoorte R. Metabolic constituents of grapevine and grape-derived products. Phytochemistry Reviews. 2010;9:357-78.

51. Klein A, Wrulich OA, Jenny M, Gruber P, Becker K, Fuchs D, et al. Pathway-focused bioassays and transcriptome analysis contribute to a better activity monitoring of complex herbal remedies. BMC Genomics. 2013;14:133.

52. Stevenson DE, Hurst RD. Polyphenolic phytochemicals-just antioxidants or much more? Cell Mol Life Sci. 2007;64:2900-16.

53. Milella RA, Antonacci D, Crupi P, Incampo F, Carrieri C, Semeraro N, et al. Skin extracts from 2 Italian table grapes (Italia and Palieri) inhibit tissue factor expression by human blood mononuclear cells. J Food Sci. 2012;77:H154-9.

54. Forester SC, Waterhouse AL. Identification of Cabernet Sauvignon anthocyanin gut microflora metabolites. J Agric Food Chem. 2008:56:9299-304.

55. Cardona F, Andres-Lacueva C, Tulipani S, Tinahones FJ, Queipo-Ortuno ML. Benefits of polyphenols on gut microbiota and implications in human health. J Nutr Biochem. 2013;24:1415-22.

56. Hidalgo M, Oruna-Concha MJ, Kolida S, Walton GE, Kallithraka S, Spencer JP, et al. Metabolism of anthocyanins by human gut microflora and their influence on gut bacterial growth. J Agric Food Chem. 2012;60:3882-90.

57. Cases S, Stone SJ, Zhou P, Yen E, Tow B, Lardizabal KD, et al. Cloning of DGAT2, a second mammalian diacylglycerol acyltransferase, and related family members. J Biol Chem. 2001;276:38870-6.

58. Haas JT, Winter HS, Lim E, Kirby A, Blumenstiel B, DeFelice M, et al. DGAT1 mutation is linked to a congenital diarrheal disorder. J Clin Invest. 2012:122:4680-4

59. Little TJ, Horowitz M, Feinle-Bisset C. Modulation by high-fat diets of gastrointestinal function and hormones associated with the regulation of energy intake: implications for the pathophysiology of obesity. Am J Clin Nutr. 2007:86:531-41.

\section{Submit your next manuscript to BioMed Central and take full advantage of:}

- Convenient online submission

- Thorough peer review

- No space constraints or color figure charges

- Immediate publication on acceptance

- Inclusion in PubMed, CAS, Scopus and Google Scholar

- Research which is freely available for redistribution 